\title{
ВІЗУАЛІЗАЦІЯ МИСЛЕННЯ У ПРОЦЕСІ ВИКЛАДАННЯ УМІ: МЕНТАЛЬНІ МАПИ
}

\section{Ольга Барабаш-Ревак}

Вроцлавський університет

Вроцлав, Республіка Польща

ORCID: 0000-0001-5418-3947

\section{VISUALISATION OF THINKING IN THE PROCESS OF TEACHING UKRAINIAN AS A FOREIGN LANGUAGE: MENTAL MAPS}

\begin{abstract}
The article presents mind maps as one of the ways to visualize the material and improve the quality of students' knowledge at Ukrainian as a foreign language lessons at the University of Wroclaw. The results of the author's experience in creating and using mind maps are proposed. They have served as a tool of distance learning of Polish-speaking students at the discipline of Ukrainian Studies during the covid-19 pandemic. Based on the results of the survey of the latter, it is argued that there is a necessity to introduce and actively use visual technologies in the field of teaching Ukrainian as a foreign language, which will allow both optimizing the process of teaching a language and increasing the student's own creative contribution to the process of mastering it.
\end{abstract}

Keywords: visualization, mind map, word cloud, Ukrainian as a foreign language.

Нинішні умови реформування освіти в Республіці Польща висувають нові вимоги до навчання іноземних мов, зокрема й української (далі - УМІ: української як іноземної). У зв'язку з цим виникає потреба вносити зміни та доповнення у програми; модернізувати навчальний процес на основі впровадження інноваційних технологій, досягнень педагогічної науки та досвіду підприємництва; вдосконалювати діяльність викладача. 3 огляду на те, що традиційні форми й методи навчання передбачають передавання знань, але не завжди формують професійні вміння й навички в майбутніх фахівців ${ }^{1}$, пріоритетна роль у навчанні сучасної молоди належить активним методам, які спрямовані на самостійну діяльність, реалізацію творчого потенціалу людини та сприяють розвиткові

1 Детальніше див.: В. Кобаль, Методика викладання у вищій школі: навчально-методичний посібник, Мукачево 2016. 
мислення. Можливість проявляти в навчанні розумову самостійність та ініціативність стає одним із важливих факторів виникнення в студентів навчальної мотивації. Иншим чинником, який відповідає іiї за розвиток, $\epsilon$ майстерність викладача іноземних мов, який активно шукає нові продуктивні технології для передавання знань та стимулювання творчости самих студентів. Одним із таких підходів $є$ інтерактивність, яка допомагає студентам досягти плавного переходу від набуття конкретних умінь до реалізації їх на практиці. Інтерактивні технології навчання, наприклад, технологія багатовимірних дидактичних інструментів Валерія Штейнберга ${ }^{2}$, стимулюють когнітивні процеси й активізують мовний і мовленнєвий матеріал в иншомовному спілкуванні студентів, розвивають їхні творчі здібності й професійно орієнтовані вміння в умовах, наближених до реальности. Така діяльність відповідає особистісно-зорієнтованому підходові до навчання, що дає змогу кожному студентові максимально проявити свої інтелектуальні й творчі здібності, заохочує самостійність та ініціативність в ухваленні рішень. Наталія Мурадова стверджує, що інтерактивне навчання - це навчання, заглиблене в процес спілкування, де необхідною $є$ наявність трьох компонентів: комунікативного (передача і збереження вербальної та невербальної інформаціі), інтерактивного (організація взаємодії у спільній діяльності) та перцептивного (сприйняття та розуміння людини людиною) ${ }^{3}$. Олена Пометун уважає, що інтерактивними можна вважати технології, які здійснюються шляхом активної взаємодії студентів під час навчання. Вони дають змогу на підставі внеску кожного з учасників у хід спільної справи отримати нові знання й організувати діяльність, починаючи від окремої взаємодії двох-трьох осіб поміж собою до широкої співпраці багатьох ${ }^{4}$. Отже, інтерактивність поєднує співпрацю мовленнєвих партнерів і керованість дій студентів з боку викладача, передбачає відмову від стандартних шляхів вирішення комунікативних завдань, забезпечує інтенсивну мовленнєву практику студентів у відносно вільній творчій атмосфері.

Нагальна потреба застосування нових технологій навчання УМІ стала надто відчутною вже на початку введення пандемічного стану, спричиненого вірусом COVID-19, коли польські виші змушені були пов-

\footnotetext{
2 Сутність ідеї полягає у заміні методики навчання, заснованої на механізмах запам'ятовування, технологією переробки знань у процесі їхнього сприйняття і засвоєння (Див.: В. Штейнберг, Н. Манько, Визуальные дидактические регулятивы логико-смыслового mипа, "Образование и наука" 2017, т. 19, № 9, с. 9-31).

Н. Мурадова, Коммуникативно-связующая роль культуры общения студентов технических заведений в интерактивном обучении, [в:] "Kz рефераты”, [Інтернет-посилання:] https://kzref.org/administraciya-orlovskoj-oblasti-upravlenie-po-delam-molodeji.html?page=8, відчитано: 26.07.2021.

4 О. Пометун, Енциклопедія інтерактивного навчання, Київ 2002, с. 13.
} 
ністю перейти в онлайн-режим. У початковий період локдауну перед освітньою системою в Польщі постало багато технічних і методичних проблем; викладачам і студентам довелося терміново (фізично й психологічно) пристосуватися до нових вимог часу та опанувати різні інструменти для синхронної роботи. Попри зміну умов функціонування, викладачам катедри україністики Вроцлавського університету необхідно було забезпечити реалізацію навчальної програми з практичного навчання української мови 5 для студентів-філологів, тобто продовжувати роботу в рамках запланованої тематики. 3 перспективи часу можна ствердити, за Пшемиславом Юзвікевичем, що „ця швидка зміна спричинила колосальні зрушення в освіті незалежно від іiі рівня"б. Локдаун змусив терміново інтенсифікувати процеси запровадження нових підходів до навчання УМІ, котрі, на думку авторки, назрівали вже віддавна.

Викладання УМІ за системою інтегрованих умінь передбачає занурення польськомовного студента вже від першого семестру в розмовні практики відповідної складности. Насичена й тематично різноманітна програма вимагає досить швидкого засвоєння великої кількости лексичного й граматичного матеріалу. На початку коронавірусної епідемії в більшости викладачів катедри україністики Вроцлавського університету виникало запитання: як забезпечити отримання максимальних ефектів онлайн-викладання УМІ? Слід підкреслити, що саме́ дистанційне виконання програми, передбаченої силабусами, не створювало особливих труднощів. Проте у зв'язку з досить високим і тривалим психологічним рівнем тривожности студентів можна говорити про зниження фінальних очікувань і результатів реалізації передбачуваної програми. Одну з головних причин такого стану слід шукати у відсутності безпосереднього „живого” контакту і взаємодії на лінії викладач - студент, студент - група. Відтак для авторки статті особливої гостроти набуло питання візуалізації навчального матеріалу та загальної організації процесу викладання УМІ. 3'явилася потреба застосування нових онлайн-технологій підготовки філологів, які б розвивали мислення, креативність, розмовну практику, а також давали змогу студентам самореалізуватися під час навчання в умовах пандемії. Оскільки заняття передбачають значний відсоток групових завдань та здебільшого медіативну роль викладача, в умовах онлайн-навчання не відразу вдалося налагодити успішний двосторонній процес. Упродовж перших місяців пандемії відчувався, з одного боку, брак студентського вміння працюва-

\footnotetext{
$5 \quad$ PNJU (пол.) - Praktyczna nauka języka ukraińskiego.

6 П. Юзвікевич, Вплив дистанційного навчання на вивчення стилістики української мови (вроилавський досвід), „Теорія і практика викладання української мови як іноземної” 2021, вип. 15, с. 29.
} 
ти дистанційно (також у групах), з іншого - брак мотивації та загальний депресивний настрій. Відтак викладачам довелося першим опанувати технічні можливості різних платформ, аби забезпечувати студентів у групах відповідною кількістю потрібного матеріалу онлайн, могти перемикатися між групами студентів, координуючи їхню роботу (платформа MS Teams) та одночасно слідкуючи за ходом їхніх дописів на віртуальній загальнодоступній дошці (аплікація OneNote). Також - окрім ролі експериментатора $з$ різними методами навчання онлайн - викладачам практичних предметів перепала ще й роль психологічного мотиватора студентів. Варто відзначити позитивний момент такої ролі: оскільки саме під час практичних занять студенти мали змогу щиро розмовляти в атмосфері відкритости, викладачі отримали неабиякий шанс перетворити це ділення емоційним станом на живе практикування української мови (особливо на 2-3 курсі бакалаврату, де одними з тем є „Здоров'я”, „Внутрішній світ людини”, „Освіта”, „Культура”). Із перспективи часу можна ствердити, що дистанційне навчання впродовж трьох семестрів мало не лише вказаний, а й низку инших позитивних аспектів: авторці статті вдалося налагодити успішну синхронну та асинхронну дистанційну співпрацю зі студентами на заняттях і поза ними (завдяки застосункові Microsoft Teams, аплікації OneNote, сервісам Wakelet, Xmind, TEDed, Edpuzzle та ин.), значно активізувати використання Інтернет-ресурсів і готових завдань (напр., на dobraforma.ku.edu), а також удосконалити свої вміння швидко створювати потрібні онлайн-матеріали для практичного навчання української мови (наприклад, на learningapps.org, wordwall.net, VideoAnt, Edpuzzle тощо). Окремим позитивним і дуже важливим ефектом са́ме дистанційного навчання став річний цикл освітньо-культурних зустрічей $з$ молодими успішними українками й українцями в рамках дисципліни „Українська мова в бізнесі й адміністрації”. Щотижневі відеозустрічі на платформі Zoom під назвою „Занурюємося в українське"” були унікальною можливістю не лише для студентів магістерської програми, а й для всіх охочих поспілкуватися з відомими представниками українського світу бізнесу, адміністрації, дипломатії, культури про специфіку їхньої професії, а - головне - попрактикувати усне і письмове мовлення українською.

3 огляду на результати психологічних досліджень (понад 80\% інформації людина сприймає зором) і досліджень пам'яти (запам'ятовується 90\% від побаченого, почутого, обговореного й активно виконаного)

Деталі й матеріали проєкту: https://www.youtube.com/channel/UCYC6vsJvxCom2f8D1 B_O2Vg/featured (офіційний ютуб-канал: Wrocławska Ukrainistyka), https://www.facebook. com/UkrainistykaWroclaw (офіційний профіль у мережі “Фейсбук”: Ukrainistyka Wrocław). 
згаданий вище принцип інтерактивности ${ }^{8}$ чи не найкраще відповідає викликам онлайн-навчання, а також сучасним тенденціям розвитку комп'ютерних технологій. Стрімкий зріст використання саме цифрових засобів передачі візуальної інформації суттєво впливає також на принципи і методи сприймання навчальної інформації інтегрального типу. Відтак особливо важливими видаються різні форми викладання УМI, що за основу мають загальний принцип візуалізації: від традиційних діаграм, графіків, таблиць, структурно-логічних схем до інтелект-карт (mind map), стратегічних карт, інфографіки, навчальних презентацій та ин. Саме необхідність пошуку, відбору та застосування найбільш ефективних методик навчання УМІ (також дистанційного) визначає актуальність вибраної проблематики статті. Авторка дотримується погляду, що візуальні технології становлять один із найпродуктивніших способів розвитку ефективної мовної комунікації, яка залежить від багатьох чинників, серед яких: вміння мовця виділити в інформаційному потоці дані, обробити їх, структуровано та логічно побудувати висловлювання, донести до слухача головну думку. Дієву допомогу в досягненні цих цілей надають ментальні карти, або інтелект-карти (,mind maps”) ${ }^{9}$, які дають змогу у стислій, вербально-образній формі глибоко й міцно засвоювати навчальний матеріал.

Проблеми та перспективи використання ментальних карт у навчальному процесі розглядали у своїх працях переважно закордонні вчені Тоні Б'юзен, Борис Санто, Браян Твісс, Річард Фостер, Хоуп Хартман, Йозеф Шумпетер, Юлія Бурдукова. Серед українських дослідників інтелектуальних карт можемо виділити Ольгу Литвиненко, Романа Медведєва, Мирославу Черній, Ірину Шахіну, Олену Пометун. Проте їхні праці мають переважно оглядовий характер і стосуються історії розвитку ментальних карт, техніки їхнього створення, загальних недоліків у процесі запровадження в навчання. До спеціальних праць, присвячених використанню ментальних карт у вивченні певних предметів (найчастіше - іноземних мов із перевагою англійської), можна зарахувати роботи Анжели Гордєєвої, Вікторії Машкіної, Світлани Процької, Наталі Орлової, Антоніни Букач, Ольги Каніболоцької, Олександри Орди, Надежди Моргунової, Світлани Приходько, Світлани Кулик, Ірени Погребенник, Олени Опана-

\footnotetext{
8 В. Кучіна, Принципи інтерактивного навчання іноземних мов та їх відповідність вимогам кредитно-модульної системи освіти у внз України, „Актуальні проблеми навчання та виховання людей з особливими потребами" 2010, № 7 (9), с. 159.

9 У сучасних дослідженнях немає єдиного загальноприйнятого значення поняття “інтелект-карта”. Насамперед це пов’язано з особливостями перекладу поняття "Mind map", що має такі найпоширеніші еквіваленти в українській мові: “інтелектуальні карти”, “ментальні карти”, “схеми мислення”, “діаграми зв’язків”, “карти розуму”, “карти уявлень”, “карти знань”, “карти пам’яті”, “асоціативні карти”.
} 
сенко. Проаналізована наукова література зі вказаного питання свідчить, що ступінь теоретичної досліджености способів візуалізації мислення в процесі засвоєння різних іноземних мов є задовільним. Хоча видається, що в методиці немає одностайного погляду на сутність цієї методики навчання, так само як немає єдиного визначення послідовности роботи 3 ментальними картами. Висвітлення ж цієї проблематики у царині викладання української мови постає надто обмеженим до початкової та середньої школи, з незначною кількістю розробок для студентів вишів різного типу, залишаючись однією з білих плям у ділянці викладання УМІ. У статті запропоновано аналіз і деякі висновки з півторарічного авторського досвіду використання технології ментальних карт (і хмар слів) під час занять із практичного навчання УМІ в дистанційному режимі. Перші результати використання цих способів візуалізації мислення відображають відповіді 17 польськомовних і 4 англомовних студентів на запитання анкети, запропонованої 2021 року (про це - нижче).

Ментальна карта - це спосіб зображення процесу мислення за допомогою схем і візуалізації, структуризації та класифікації ідей. Иншими словами, карти відображають те, як виникають, формуються думки і запам'ятовуються дані в мозку людини; допомагають засвоїти відмінності між здатністю та ефективністю зберігання інформації. В освіті карти виконують три потужні функції: а) як інструмент для презентацій (бажана альтернатива PowerPoint), б) як спосіб укладання плану тексту, в) як навчальний засіб (обробляючи мову, картографічне мислення робить українську як іноземну доступнішою для тих, хто нею не володіє). Доцільність використання інтелект-карт під час співпраці зі студентами української філології Вроцлавського університету полягає у формуванні їхньої иншомовної комунікативної компетенції. На думку авторки, технологія "mind map" чи не найефективніше впливає на розвиток иншомовленнєвої діяльности студента-філолога, розвиваючи навички иншомовного говоріння та письма. Психологічною основою методу $\epsilon$ асоціативне мислення, яке дає змогу бачити не просто об'єкт навколишнього світу сам по собі, а у зв'язку з иншими об'єктами. Ментальні карти дозволяють скоротити процес засвоєння навчальних матеріалів, підвищивши ступінь запам'ятовування інформації. При складанні інтелект-карти працюють обидві півкулі головного мозку, оскільки в процесі їхньої побудови бере участь більшість каналів сприйняття. Під час аналізу інформації працює ліва півкуля, яка відповідає за логіку. При добиранні графічних образів до слів на гілках інтелект-карти активізуються нові розумові процеси, які до цього моменту не були задіяні. До роботи лівої півкулі мозку підключається права півкуля, що відповідає за образи. Так зв'язується робота обох півкуль - від асоціацій до логіки і назад. У цьому важлива перевага технології інтелект-карт: вони допомагають розвивати 
креативне і критичне мислення, пам'ять і увагу студентів, а також роблять навчальні процеси цікавішими і результативнішими. Мета створення карт може бути різна: структурування та запам'ятовування складного матеріалу, занотовування інформації, підготовка доповіди, проєкту, складання планів, з'ясування для себе якогось питання тощо. Цей метод ефективний при вивченні лексичних тем (у повторенні, актуалізації та систематизації лексики); для складання монологічного висловлювання; для роботи з граматичним матеріалом (за допомогою карти можна продемонструвати будь-яке граматичне правило або конструкцію, а для розуміння винятків, особливих випадків і прикладів застосування достатньо виділити їх в окремі гілки та зробити на них акцент). За словами Ірини Шахіної та Романа Медведєва, карти знань привертають увагу авдиторії, налаштовуючи іiі до співпраці; роблять заняття і презентації органічними, такими, що приносять радість і викладачеві, і студентам; сам матеріал стає гнучким, його можна легко пристосовувати до змінних умов, натомість студенти глибше розуміють предмет: ментальні карти не тільки зберігають факти, але і демонструють взаємозв'язки між ними ${ }^{10}$.

Ментальні карти є однією з розробок Тоні Б'юзена ${ }^{11}$, який стверджує, що такий метод є одночасно прикладною програмою та формою графічного вираження радіантного мислення людини ${ }^{12}$. Він указує, що в ході еволюційного розвитку мисленнєвих процесів люди використовували лише окремі промені радіанта замість того, щоби задіяти весь потужний багатовимірний механізм ${ }^{13}$. Відтак, автор пояснює карти як записи, породжені творчим мисленням, які в буквальному сенсі представляють легкий для читання план думок людини, що поступово розширюється залежно від того, як ці думки виникають у неї в голові. План нагадує діаграму або павутину, в центрі якої знаходиться головна ідея або тема, від неї послідовно відгалужуються підтеми, які самі стають центрами наступних асоціацій (1 рівень), потім конкретизовані ідеї (2 рівень) і так далі до периферії, практично до безкінечности. У міру розростання інтелект-карти деякі їі периферійні ідеї можуть набути нового важливого значення настільки, що стають новими центрами. Таким чином з'являється можливість поглянути на початкову структуру з різних перспектив, що сприяє вивченню всієї системи взаємозв'язків у рамках певної концепції. Для посилення змісту використовуються зображення та кольо-

10 І. Шахіна, Р. Медведєв, Використання ментальних карт у навчальному процесі, „Наукові записки. Серія: Проблеми методики фізико-математичної і технологічної освіти” 2015, вип. 8 (III), с. 75-76.

11 Т. Бьюзен, Б. Бьюзен, Супермылиление, [в:] “LoveRead.ec”, [Інтернет-посилання:] http://loveread.ec/contents.php?id=55086, відчитано: 26.07.2021.

12 Там само, с. 12.

13 Там само. 
ри (найменше - три), які дозволяють виділяти і структурувати думки. Найпростіше використання кольору - це створення центрального образу і гілок, що виходять 3 нього, одним кольором, виділення гілок підпунктів іншим кольором, а написи над ними третім кольором. На думку Т. Б'юзена, для особливо важливих питань бажано виділяти гілки теплими кольорами (червоний, оранжевий, жовтий, зелений), а написи над ними робити однокольоровими (чорний і сірий). Для інших елементів можна робити гілки ахроматичними, а написи над ними - холодними кольорами. Також можна поєднувати холодні і теплі кольори. Усі способи допомагають підвищити привабливість, оригінальність карти і збільшити творчий запал при іiі створенні та використанні, а в кінцевому результаті - краще запам'ятати/зрозуміти інформацію. Мапи - це крок уперед на шляху прогресу від лінійного через латеральне до радіантного мислення.

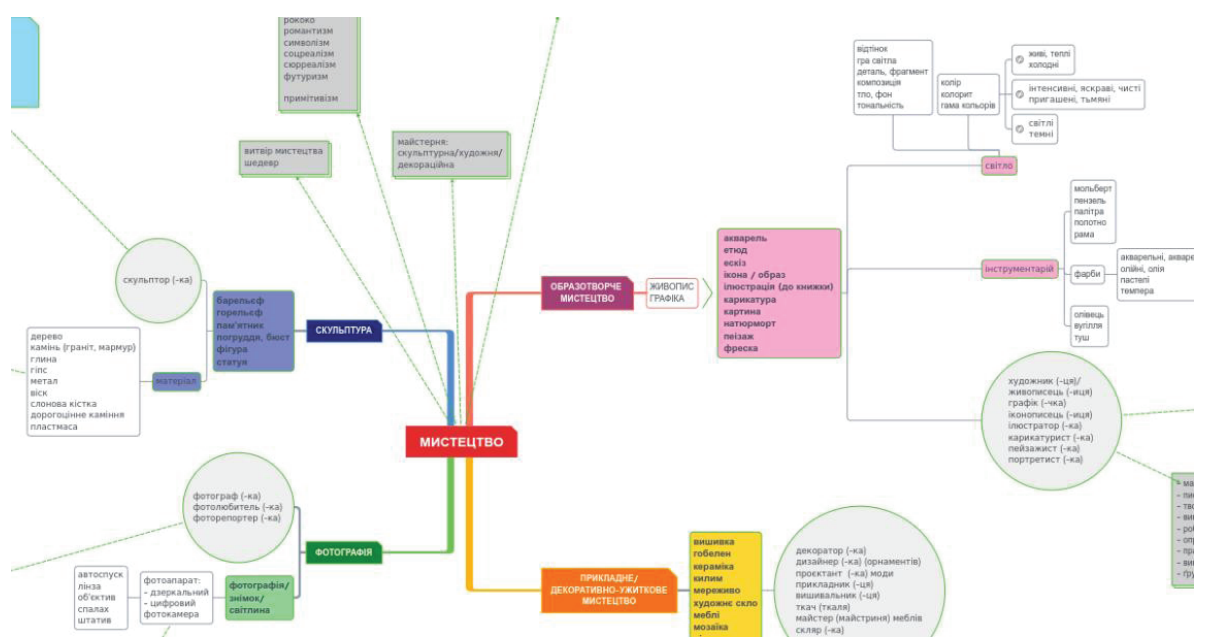

Рис. 1. Ключовий фрагмент ментальної мапи „Мистецтво”

Вивчення УМІ вимагає цілісного сприймання та аналізу мовних явищ, під час якого студент здійснює їхню смислову компресію. Усі процеси вивчення мовних явищ та перенесення знань у практичну діяльність тісно взаємопов'язані. Широке використання технології інтелект-карт дозволяє організувати процес засвоєння від первинного сприйняття мовного явища до глибокого розуміння та практичного використання, що стає основою формування мовної та мовленнєвої компетентностей студентів. Застосування карт на заняттях із УМІ дозволяє: 1) створити мотивацію до оволодіння українською мовою, пропонуючи способи, які економлять час „опрацювання” і запам'ятовування нових слів; 2) організувати індивідуальну, групову та колективну діяльність студентів, які самі ж генерують нові ідеї (значень слів, варіантів перекладу, контекстних значень, 
синонімів, антонімів тощо); 3) здійснювати диференційований підхід до студентів (допомагаючи відпрацьовувати навички складання планів, структурування, знаходження логічних асоціативних зв'язків між словами, викладач сприяє подоланню причин, які впливають на студентську успішність); 4) організувати проєктну діяльність (ментальну мапу можна використовувати для представлення результатів); 5) навчити користуватися словниками, довідниками з метою оволодіння новими мовними засобами та збільшення обсягу знань профільно-орієнтованого характеру.

Для інтенсифікації процесу складання карт пам'яти розроблені численні комп'ютерні програми ${ }^{14}$ та вебсервіси, котрі дозволяють уводити виділені ключові фрази у готові шаблони або будувати власні карти. Після опанування однієї з таких програм (Xmind) авторка статті розпочала активне використання ментальних мап - під час онлайн-занять, як домашні завдання та для самостійної роботи. Оскільки при створенні карт задіються уява, творче та критичне мислення і всі види пам'яти, це дозволяло студентам вивчити більшу кількість матеріалу за обмежену кількість годин, передбачених на курс практичного навчання української мови. На заняттях з інтегрованих умінь авторка успішно використовувала інтелект-карти для опрацювання великих пластів нового лексичного матеріалу, розбиваючи його на кілька окремих сегментів у межах однієї більшої карти; роботи з граматичним матеріалом (наприклад, опрацювання парадигми відмінків різних частин мови чи парадигми повних прикметників); навчання усного монологічного висловлювання (інтелект-карта як вербальна опора). Студенти випускних курсів використовували карти при підготовці до іспиту з практичного навчання української мови, оскільки для запам'ятовування і повторення інформації витрачалося менше часу, а їі відтворення ставало більш осмисленим.

Найбільш ефективні результати використання ментальних карт авторці вдалося отримати при введенні нового лексичного матеріалу та його контролі. Перед початком кожного нового модуля студенти отримували лексику з теми у вигляді мапи, складеної за принципом високої частотности використання лексичних одиниць, які надалі використовувалися в різноманітних видах роботи на заняттях. Складніші випадки слововживання ілюструвалися прикладами - 3 огляду на специфіку людської пам'яти, яка влаштована так, що інформація запам'ятовуєть-

14 Авторка використовує програму Xmind (https://www.xmind.net/), яка дає змогу створювати зокрема й спільні ментальні мапи. Цю функцію програми успішно випробувано під час співпраці з катедрою української та іноземних мов Тернопільського національного технічного університету ім. І. Пулюя. Xmind дозволяє синхронну побудову карти: одна особа працює оператором, який уводить потрібну інформацію в комп'ютер. Таким чином інтелект-карта стає результатом колективної праці, а можливість роздрукувати у потрібній кількості примірників дозволяє кожному учаснику використовувати ії в своїй роботі. 
ся в контексті (саме тому створення ментальної карти - це і $є$ фіксація каркасу, на який легко нанизуються нові слова). Для самостійної роботи 3 новим лексичним матеріалом иноді також давалася схема ментальної карти. Після того, як теми або цілий модуль були вивчені, подібний каркас пропонувався для підсумкової роботи над лексикою. Такий вид контролю показує викладачеві, наскільки добре студенти засвоїли матеріал, а також дозволяє їм самим оцінити свої знання. Окрім того, завдяки мапам студент має чітке бачення всієї теми, iї головних і другорядних елементів. Завдяки можливості демонстрації екрану (на платформі MS Teams) стала можлива також побудова інтелект-карт на занятті (у малих групах) із пізнішим обговоренням, а також спільне створення однієї більшої мапи - як документація результатів мозкового штурму. Виявилося, що побудова карт займала студентам значно менше часу, ніж ведення конспектів чи словничків до теми, додатково таке відображення інформації саме в собі є логічно організованим і вже від початку сприяє утворенню мережевих структур, даючи змогу студентові поглянути на проблематику повністю та з урахуванням усіх особливостей.

Як показала авторська практика, ментальні мапи можна успішно використовувати і на заняттях із розвитку письмових умінь. Наприклад, у рамках предмета „Творче письмо” вдалося випробувати цю технологію для навчання побудови плану твору: інтелектуальна карта допомагала студентам чітко визначити структуру та розставити акценти в потрібних місцях, що значно полегшувало написання будь-якої письмової роботи. Основні (відпрацьовані практикою) рекомендації для студентів полягали у тому, щоби починати інтелект-карту з центрального образу, який відображає тему. Після цього слід підібрати відповідні базові порядкові ідеї для головних гілок інтелект-карти або основних розділів твору. На цій стадії слід приділяти пильну увагу правильній постановці питань або формулюванню теми, оскільки тут нерідко ховаються ключі до визначення базових порядкових ідей. Далі - налаштуватися на вільний політ думки. На цій стадії слід активно використовувати коди (колірні, символьні або їх комбінації) для організації перехресних посилань або зв'язків між різними сегментами карти. Останнім етапом є ретельна перевірка й корекція карти до моменту, аж доки результат стане задовільним. Добре організована інтелект-карта забезпечує студентові чітке уявлення про всі основні підрозділи у творі, ключові ідеї, а також зв'язки між ними. Варто радити студентам, аби на першій стадії укладання тексту писати 3 максимальною швидкістю, пропускаючи будь-які „проблемні” місця, складні поняття або граматичне оформлення. Увагу слід приділяти в першу чергу безперервності потоку думок, пам'ятаючи про те, що до „проблемних” місць можна буде повернутися пізніше. У випадку творчої кризи потрібно лише додати ряд порожніх гілок, що відходять від уже 
існуючих ключових слів і образів, і „схильність до заповнення пустот”, характерна для мозку, зіграє свою роль, стимулюючи нові асоціації та продукти образного мислення. У таких випадках корисно нагадати собі про безмежну асоціативну здатність мозку і вміння брати до уваги всі без винятку думки, особливо ті, що могли видатися спочатку “абсурдними”. Також хотілося би відзначити, що електронний текстовий редактор у цьому випадку є добрим доповненням до методу інтелект-карт, оскільки надає додаткові можливості й гнучкість у редагуванні тексту.

3 досвіду варто відзначити, що на початковому етапі вивчення УМІ карти розуму краще пропонувати в готовому вигляді. Викладачеві слід складати ментальну карту так, щоб не тільки охопити всю лексику відповідно до програми, але й передбачити різні асоціації, які можуть виникнути у студентів під час роботи з лексичним матеріалом. Це дозволяє відразу перейти до розгляду й аналізу нової лексики, поданої з прикладами вживання (та ілюстраціями), а також використовувати готові комунікативні моделі. Таким чином студент уже на початковому етапі вивчення УМІ легко будує прості речення, засвоюючи мову безпосередньо в дії. Иншим вдалим прикладом використання візуалізації під час занять з УМІ $\epsilon$ невеликі хмари слів (тегів $)^{15}$. Вони також полегшують розуміння і запам'ятовування різноманітного матеріалу (фонетичного, лексичного, граматичного), спрощують роботу з текстом, сприяють розвиткові усного й письмового мовлення. Окрім того, для тематичної хмари слів можна підібрати спеціальний кшталт, який додатково візуалізуватиме ключове слово. Як виявила авторська річна практика, цю технологію легко використовувати вже зі студентами першого курсу. На початку викладачка (демонструючи свій екран у платформі MS Teams) записувала під диктант студентів їхні асоціації до теми, а згодом польськомовні студенти були спроможні виконувати таку вправу самостійно / у парах, надсилаючи решті групи невелику готову хмару слів у чаті. Така технологія, окрім стимулювання креативности і ефективного освоєння кириличної розкладки клавіатури, щоразу ставала добрим матеріалом для подальшої роботи над помилками у словах. Ще иншим прикладом використання хмар слів $є$ візуалізація прикладів слів за певним правилом (саме так студенти закріплювали на заняттях із фонетики теми про апостроф, м'який знак, буквосполучення „,̆о-ьо”, спрощення, чергування). Використання яскравої графіки у вигляді хмар слів дозволяє зробити акценти на ключових моментах теми, що сприяє швидшому опануванню / переосмисленню та систематизації матеріалу завдяки активному залученню зорової пам'яти.

Авторка впродовж року неодноразово переконувалася, що експериментальне введення ментальних мап та хмар слів на першому курсі бака-

15 Авторка використовувала сервіс https://wordart.com/. 
лаврської програми виявилося успішним (і як же потрібним!) елементом технології скафолдингу - тимчасової допомоги (,„риштувань”) у навчанні УМІ. Ця стратегія підтримки студента на занятті передбачає використання різних видів контекстної допомоги (напр., використання спрощеної мови, зображень, спільного та практичного навчання). Спершу викладач сприяє цій підтримці, а коли студенти стають більше кваліфікованими, поступово знімає скафолдинг. Лев Виготський ${ }^{16}$ підкреслював важливість підтримки вчителя, котрий на початкових етапах навчання перебуває поряд зі студентом, визначає йому конкретні рівні “риштування", таким чином допомагаючи набратися впевнености у собі та ефективніше виконувати наступні, складніші завдання. У такому процесі навчання викладач виконує роль не лише джерела інформації, а й потужного мотиватора, сприяючи розвиткові творчої особистости студента, появі позитивної мотивації до пізнавальної діяльности, а також задоволенню потреби самореалізації та самовдосконалення.

На пізнішому етапі вивчення мови доцільно запроваджувати побудову спільної мапи на занятті чи самостійне створення студентами власних карт. Слід зауважити, що розумова карта, яка створюється разом зі студентами на занятті, може бути відмінною від оригіналу викладача, позаяк у кожної людини виникають свої асоціації, пов'язані з тим чи иншим словом (словосполученням). Особливість інтелект-карт полягає в тому, що вони не можуть бути завершені повністю, адже студенти постійно доповнюють та розширюють їх - залежно від того, як виникають нові ідеї та збільшується лексичний запас. У студентів з різною мовною підготовкою в кінцевому підсумку створюються різні інтелект-карти, ба більше, важливу роль відіграють фонові знання та особистий досвід ${ }^{17}$. Крім того, ментальна карта не має на меті відповісти на всі питання та все детально розповісти, вона слугує схемою, йдучи за якою студент зможе розв'язати поставлені завдання. Для прикладу, погляньмо на ключовий фрагмент ментальної карти для теми “Апостроф” (рис. 2), який дає змогу сприйняти матеріал цілісно, але в той же час не замінює детальних презентацій, становлячи радше доповнення до них.

Нижче пропонуємо розглянути авторські приклади вибраних етапів і компонентів створення інтелект-карти до теми “Зовнішність" (програма 1 курсу бакалаврського навчання). У роботі в групах / парах студенти спершу записують ключове слово “Зовнішність”, далі - на гілках першого ряду - занотовують найважливіші асоціації (рис. 3). Бажано залишати

\footnotetext{
16 Див.: Л. Выготский, Педагогическая психология, Москва 1991.

17 О. Орда, Д. Новицька, Інтелект-карти як ефективний метод навчання іноземної мови майбутнього інженера, "Вчені записки ТНУ імені В. І. Вернадського. Серія: Психологія” 2020, т. 31 (70) № 4, с. 232.
} 


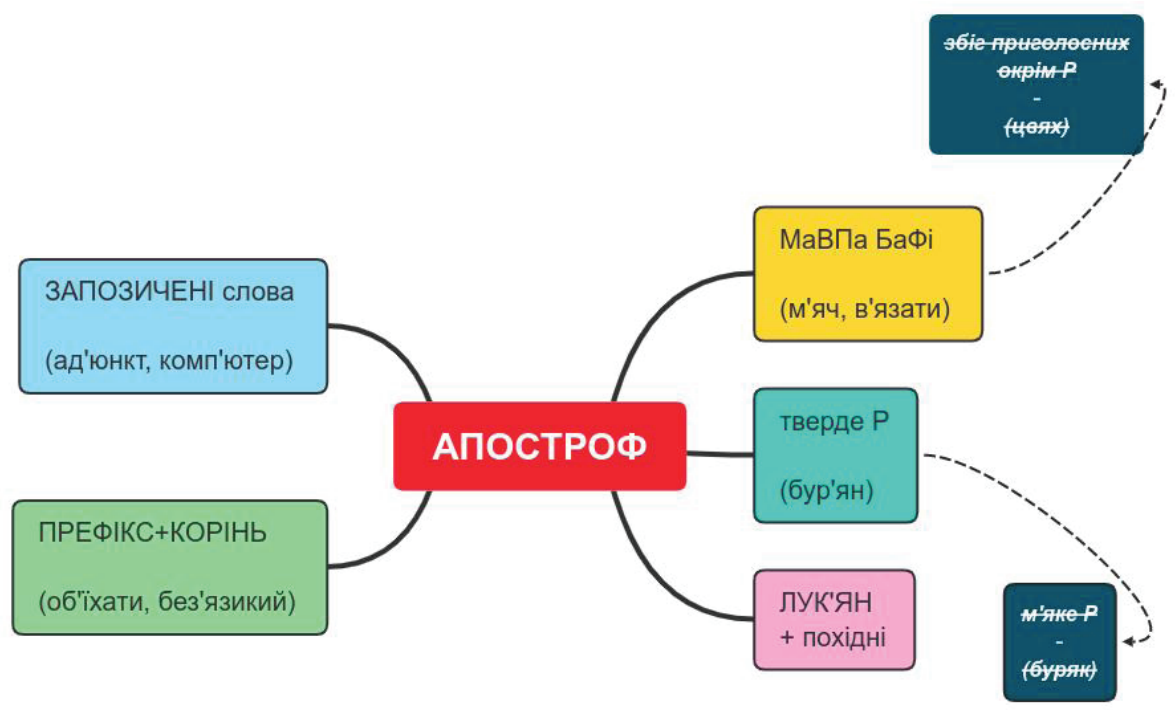

Рис. 2. Основний фрагмент ментальної карти „Апостроф”

також незаповнені гілки, щоби під час перегляду карти згодом можна було іiі доповнити. Записуючи, а потім переглядаючи ідеї, знаходяться нові зв’язки між концепціями, які були досі непоміченими. Крім того, сам спосіб створення карти переводить мозок у режим креативности.

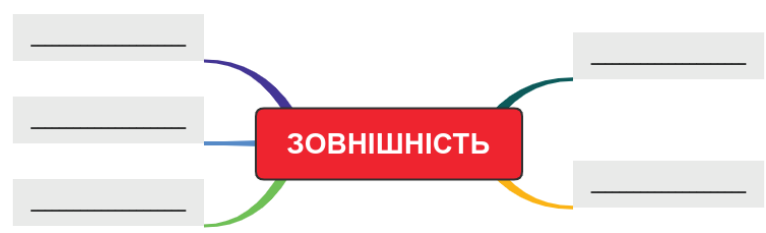

Рис. 3. Початковий етап створення карти “Зовнішність”

Потім, розбудовуючи гілки першого ряду, студенти входять у деталі конкретних елементів - так з'являється другий ряд - i т. д. Заповнюючи гілки карти, студенти актуалізують уже набутий мовний досвід та доповнюють його новим. Окремі рівні такої карти можна позначати різними кольорами та відповідним розміром шрифта (рис. 4).

В умовах створення обширнішої інтелект-карти змістовним виявилося поєднання кількох менших блоків у більший (рис. 5).

Такий окремий блок може стати самостійним матеріалом для різноманітних завдань у межах загальної теми, наприклад: закріплення складної для польськомовного студента парадигми відмінювання слова “волосся" (однина, на відміну від польського włosy - множина) чи засвоєння парадигм відмінювання прикметників. Завдання можна розши- 
рити парадигмою займенників, які для поляків теж становлять складний матеріал.

Додатковим елементом інтелект-карти стає зображення (ілюстрація), пришвидшуючи процес семантизації лексичних одиниць та їхнє запам'ятовування (рис. 6).

У процесі роботи над власними інтелект-картами, виходячи 3 конкретних потреб польськомовних студентів, авторка дещо розширила первісний обсяг концепції Т. Б’юзена. Додаючи до інтелект-мапи синоніми (антоніми), поля з прикладами використання конкретних лексичних / граматичних елементів, вдалося створити опорний конспект для вивчення УМІ (рис. 7).

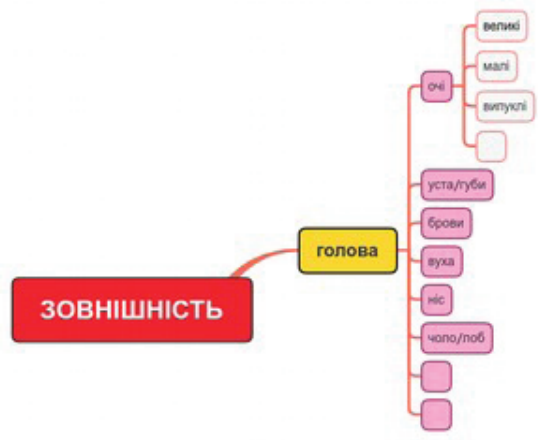

Рис. 4. Фрагмент ментальної мапи “Зовнішність людини”

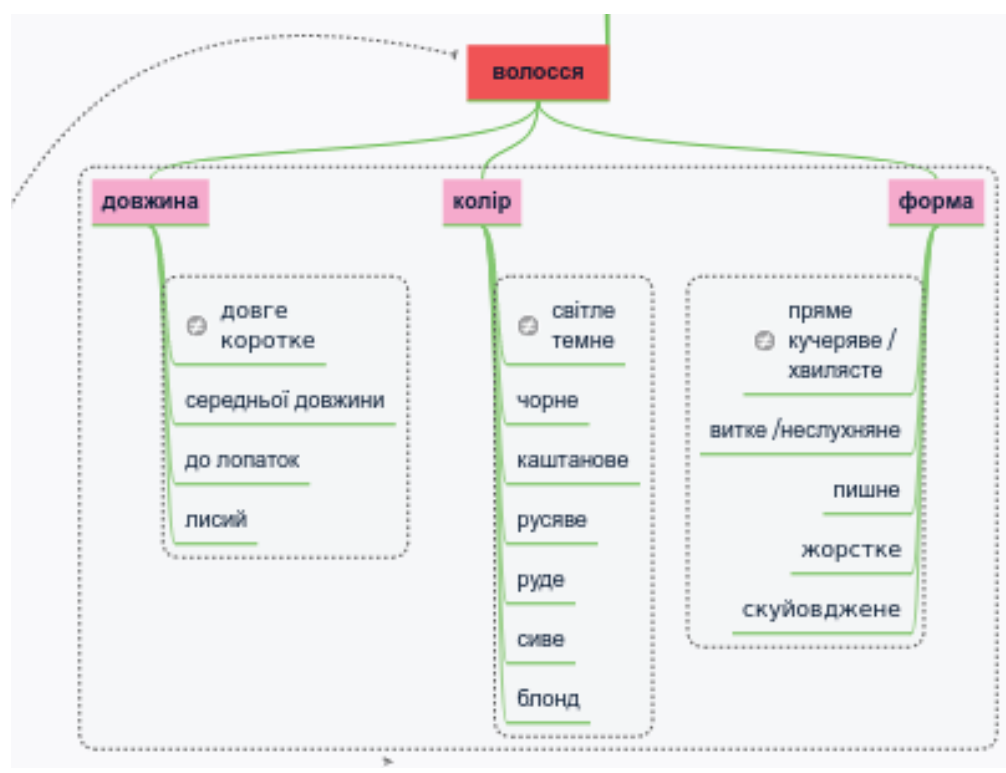

Рис. 5. Об’єднані блоки 


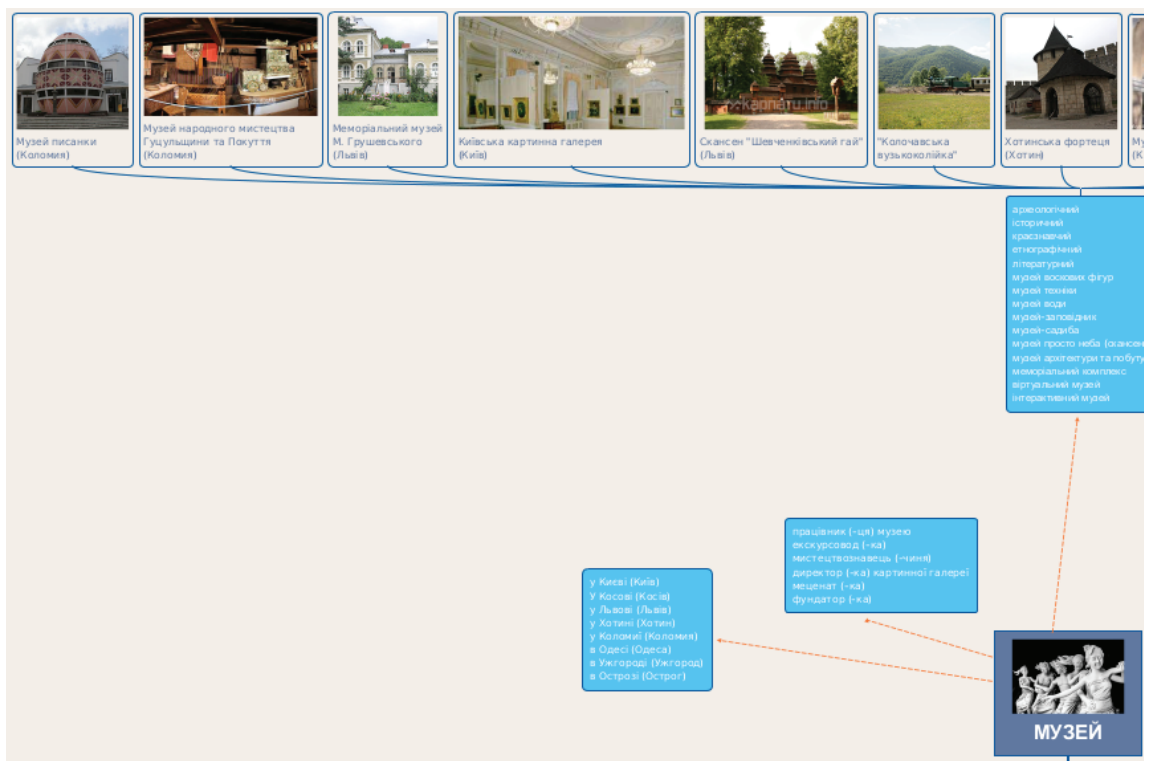

Рис. 6. Фрагмент мапи з додатковими ілюстраціями

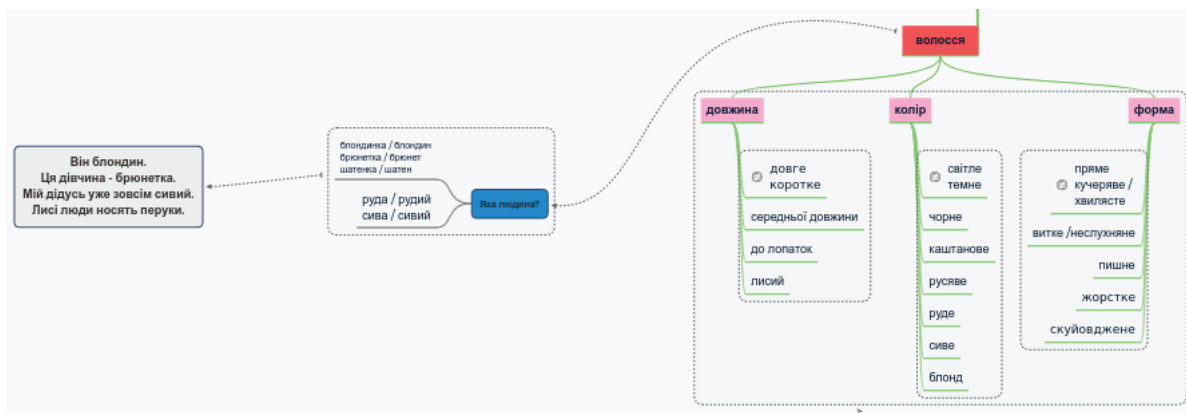

Рис. 7. Фрагмент мапи „Зовнішність”, розширений синонімами, анотонімами та полями з прикладами

Готовий проєкт ментальної карти, розширений до рівня опорного конспента, може виглядати прикладово так (рис. 8):

Використання інтелект-карт дозволяє не лише забезпечити особистісно орієнтовану модель навчання чи вможливлює оригінальний підхід до побудови сучасного заняття з УМІ. Для кращого розуміння студентського досвіду і специфіки використання ними ментальних карт у процесі вивчення УМІ авторка створила анкету з відкритими і закритими питаннями: 1) Чи робота 3 ментальними мапами є для Тебе новинкою в процесі вивчення іноземних мов? 2) Наскільки помічними є ментальні мапи у процесі вивчення української мови? 3) Вкажи, як Тобі працювалося $з$ ментальними мапами; 4) Чи ілюстрації допомагають зрозуміти 


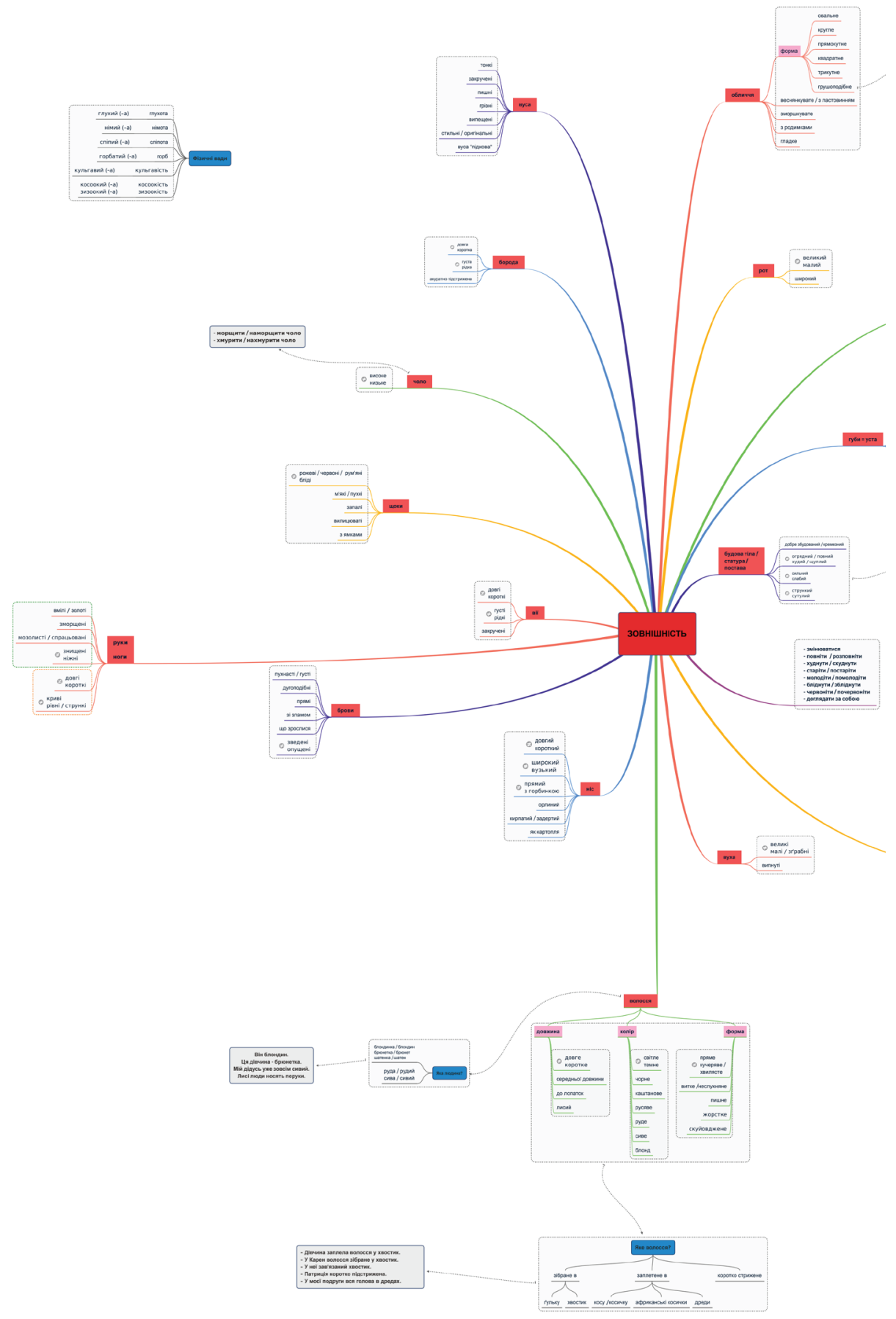

Рис. 8. Проєкт опорного конспекта на базі ментальної мапи “Зовнішність” 


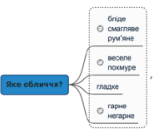

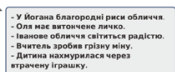

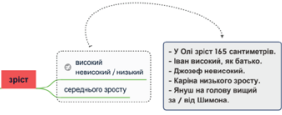

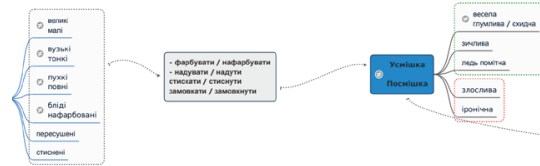
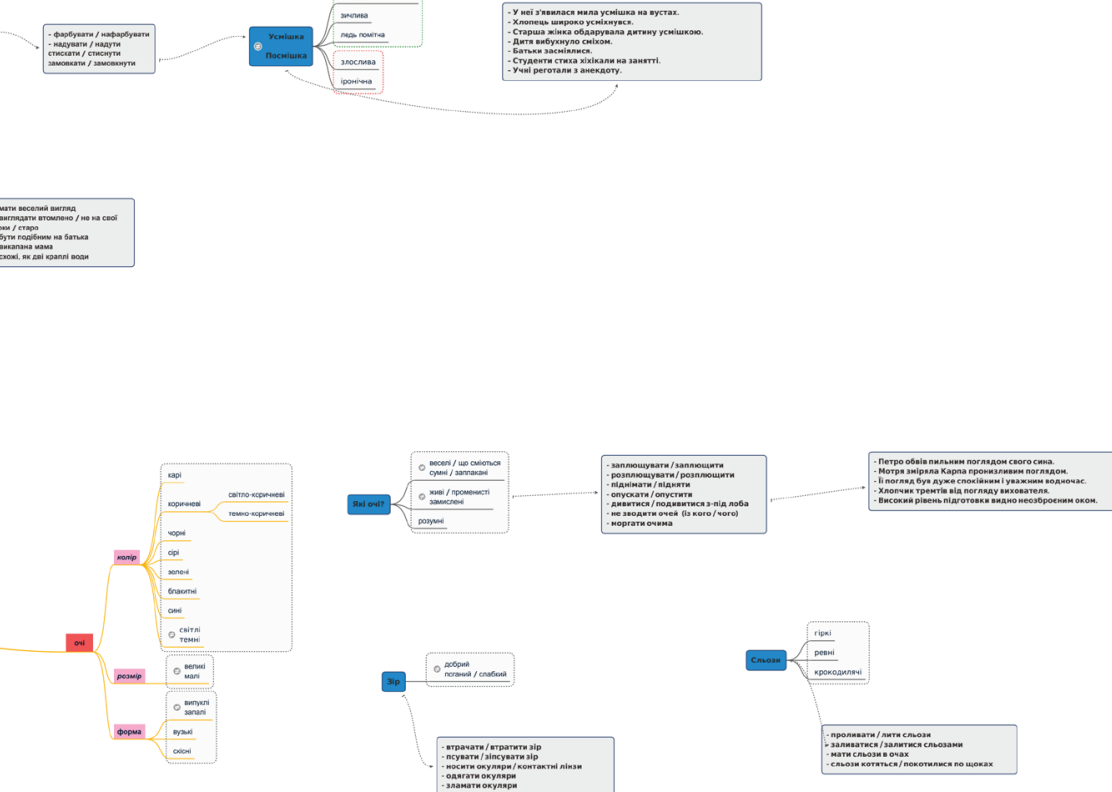
і запам'ятати матеріал? 5) Яка інформація на мапах була непотрібною? 6) Опиши, як саме допомагають Тобі ментальні мапи; 7) Опиши недоліки ментальних мап або свої труднощі у роботі з ними; 8) Вкажи, як можна удосконалити ментальні мапи. Відтак у результаті останнього з проведених анкетувань студентів (17 осіб) після одного семестру роботи зі запропонованими ментальними картами (лексика і частково граматика) можна констатувати певні факти:

- процес творення викладачем ментальних карт до конкретних тем вимагає грунтовного осмислення теми й відбору найважливішої та найпотрібнішої лексики. Це надзвичайно трудомісткий процес, натомість готова ментальна карта стає досконалою базою для швидкого створення вправ різного типу й складности, сприяючи розвиткові різноманітних комунікативних навичок та творчого письма;

- використання студентами ментальних карт дозволяє значно швидше опанувати лексичну семантику (та лексико-граматичні конструкції), морфологічну парадигму; систематизувати попередні знання; швидше навчитися правильних способів побудови речень та структурованих текстів;

- використання ілюстративного матеріалу в ментальних мапах допомагає студентам легше запам'ятати нові слова й створювати потрібні асоціації;

- процес групового створення хмар слів під час онлайн-занять актуалізує поперередні знання студентів, сприяє розвитку творчого мислення. Анкетування виявило, на жаль, низький рівень обізнаности респондентів зі вказаною технологією: майже 90\% студентів указали, що робота 3 ментальними мапами $є$ для них новинкою у процесі вивчення іноземних мов. Водночас $60 \%$ ствердили, що ментальні мапи були дуже помічними й водночас не викликали труднощів у зрозумінні. Таке співвідношення результатів свідчить про необхідність активнішого застосування візуальних технологій у царині викладання УМІ та створення ширшої бази тематичних напрацювань, що дозволить заощадити час викладачів, оптимізувати співпрацю зі студентами та збільшити власний вклад студента у процес вивчення УМІ. Загалом же використання різних способів візуалізації мислення відповідає одній із головних цілей викладання УМІ - формуванню комунікативних компетенцій студента - та реалізує принцип інтерактивности. Можливості карт дозволяють: поліпшити пам'ять, розвинути креативність, швидко нагадати / вивчити факти, слова і конструкції; структурувати письмові роботи; підсумовувати інформацію; організувати взаємодію між студентами. Інтелект-карти дають змогу в стислій, вербально-образній формі глибоко, міцно засвоювати навчальний матеріал, тому використовувати цю технологію можна на різних етапах занять при вивченні як української мови, так і літератури. 


\section{БІБЛІОГРАФІЯ}

Bukač Antonina. 2013. Zastosuvannâ tehnologï intelekt-kart (Mindmaps) u navčal'novihovnomи procesì. Bìla Cerkva: NMC [Букач Антоніна. 2013. Застосування технології інтелект-карт (MindMaps) у навчально-виховному проиесі. Біла Церква: НМЦ].

B'ûzen Toni, B'ûzen Barri. Supermyšlenie. Minsk. W: http://loveread.ec/contents. php?id=55086 [Бьюзен Тони, Бьюзен Барри. Супермылиление. Минск. B: http:// loveread.ec/contents.php?id=55086].

Gordêêva Alla. 2012. İntelektual'nì karti âk zasib formuvannâ ìnšomovnoï komunìkativnoï kompetentnostì majbutnih filologìv. "İnozemnì movi” № 4: 51-58 [Гордєєва Алла. 2012. Інтелектуальні карти як засіб формування іншомовної комунікативної компетентності майбутніх філологів. “Іноземні мови” № 4: 51-58].

Jones Brett, Ruff Chloe, Snyder Jennifer, Petrich Britta, Koonce Chelsea. 2012. The Effects of Mind Mapping Activities on Students' Motivation. "International Journal for the Scholarship of Teaching and Learning” vol. 6 № 1 Article 5. W: https://digitalcommons. georgiasouthern.edu/cgi/viewcontent.cgi?article $=1314 \&$ context $=$ ij-sotl

Kobal' Vasil'. 2016. Metodika vikladannâ u visìj školì: navčal'no-metodičnij posibnik. Mukačevo: Vid-vo MDU [Кобаль Василь. 2016. Методика викладання у вищій школі: навчально-методичний посібник. Мукачево: Вид-во МДУ].

Kučìna Valentina. 2010. Principi interaktivnogo navčannâ inozemnih mov ta ih vidpovidnist' vimogam kreditno-modul'noï sistemi osviti $u$ vnz Ukraïni. "Aktual'nì problemi navčannâ ta vihovannâ lûdej z osoblivimi potrebami” № 7 (9): 156-165 [Кучіна Валентина. 2010. Принщипи інтерактивного навчання іноземних мов та їх відповідність вимогам кредитно-модульної системи освіти у внз Украӥни. “Актуальні проблеми навчання та виховання людей з особливими потребами” № 7 (9): 156-165].

Muradova Natal'â. Kommunikativno-svâzû̂sâ̂ rol' kul'tury obŝeniâ studentov tehničeskih zavedenij $v$ interaktivnom obučenii. Orel. W: https://kzref.org/administraciyaorlovskoj-oblasti-upravlenie-po-delam-molodeji.html?page=8 [Мурадова Наталья. Коммуникативно-связующая роль культуры общения студентов технических заведений в интерактивном обучении. Орел. B: https://kzref.org/administraciyaorlovskoj-oblasti-upravlenie-po-delam-molodeji.html?page=8].

Orda Oleksandra, Novic'ka Darì̂. 2020. İntelekt-karti âk efektivnij metod navčannâ ìnozemnoï movi majbutn'ogo ìnženera. "Včenì zapiski TNU ìmenì V. İ. Vernads'kogo. Seriâ: Psihologiâ". Т. 31 (70) № 4: 230-234 [Орда Олександра, Новицька Дарія. 2020. Інтелект-карти як ефективний метод навчання іноземної мови майбутнього інженера. "Вчені записки ТНУ імені В. І. Вернадського. Серія: Психологія”. Т. 31 (70) № 4: 230-234].

Orlova Nataliia. 2017. Efficiency of mind mapping for the development of speaking skills in students of non-linguistic study fields. "Science and education" Issue 6: 151-161.

Pogrebennik İrena. 2018. Mental'nì karti pri vikladanni ukraïns'koï movi i literaturi u zakladah profesìno-tehničnoï osviti. "Ukraïns'ka profesìjna osvìta" № 4: 70-76 [Погребенник Ірена. 2018. Ментальні карти при викладанні української мови i літератури у закладах професійно-технічної освіти. "Українська професійна освіта" № 4: 70-76].

Pometun Olena. 2007. Enciklopediâ interaktivnogo navčannâ. Kiïv: Vidavnictvo ASK [Пометун Олена. 2007. Енцииклопедія інтерактивного навчання. Київ: Видавництво АСК]. 
Swan Hobard, 2010. Mind Mapping: Learning and Teaching with Both Sides of the Brain. W: https://www.teachingvillage.org/2010/02/10/mind-mapping-learning-andteaching-with-both-sides-of-the-brain/.

Šahìna İrina, Medvedêv Roman. 2015. Vikoristannâ mental'nih kart u navčal'nomu procesì. "Naukovì zapiski. Serìa: Problemi metodiki fiziko-matematičnoï ì tehnologičnoï osviti” vip. 8 (III): 73-78 [Шахіна Ірина, Медведєв Роман. 2015. Використання ментальних карт у навчальному процесі. "Наукові записки. Серія: Проблеми методики фізико-математичної і технологічної освіти” вип. 8 (III): 73-78].

Štejnberg Valerij, Man'ko Nataliâ. 2017. Vizual'nye didaktičeskie regulâtivy logikosmyslovogo tipa. “Obrazovanie i nauka”. Т. 19 № 9: 9-31 [Штейнберг Валерий, Манько Наталия. 2017. Визуальные дидактические регулятивы логико-смыслового типа. "Образование и наука". Т. 19 № 9: 9-31].

Ûzvìkevič Pšemislav. 2021. Vpliv distancìjnogo navčannâ na vivčennâ stilistiki ukraïns'koï movi (vroclavs'kij dosvid). "Teoriâ ì praktika vikladannâ ukraïns'koï movi âk ìnozemnoï” vip. 15: 29-39 [Юзвікевич Пшемислав. 2021. Вплив дистанційного навчання на вивчення стилістики украйнської мови (врочлавський досвід). "Теорія і практика викладання української мови як іноземної” вип. 15: 29-39].

Vygotskij Lev. 1991. Pedagogičeskaâ psihologiâ. Moskva: Pedagogika [Выготский Лев. 1991. Педагогическая психология. Москва: Педагогика].

\section{WIZUALIZACJA MYŚLENIA W TRAKCIE NAUCZANIA JĘZYKA UKRAIŃSKIEGO JAKO OBCEGO: MAPY MENTALNE}

Streszczenie: W artykule omówiono mapy mentalne jako jeden ze sposobów wizualizacji materiału i podniesienia poziomu oraz jakości stanu wiedzy studentów na zajęciach z języka ukraińskiego jako obcego na Uniwersytecie Wrocławskim. Zaprezentowano w nim wyniki autorskiego doświadczenia dotyczącego stworzenia oraz wykorzystania map na potrzeby zdalnego nauczania polskojęzycznych studentów-ukrainistów podczas pandemii Covid-19. Na podstawie rezultatów ankietowania studentów stwierdzono konieczność wprowadzenia oraz aktywnego wykorzystania technologii wizualnych w dziedzinie nauczania języka ukraińskiego jako obcego. Pozwoli to zarówno na optymalizację procesu nauczania języka, jak i na zwiększenie wkładu twórczego studenta w procesie jego akwizycji.

Słowa kluczowe: wizualizacja, mentalna mapa, chmura słów, język ukraiński jako obcy.

\section{ВІЗУАЛІЗАЦІЯ МИСЛЕННЯ У ПРОЦЕСІ ВИКЛАДАННЯ УМІ: МЕНТАЛЬНІ МАПИ}

Анотація: У статті представлено ментальні мапи як один із способів унаочнення матеріалу та шляхів покращення якости знань студентів на заняттях УМІ у Вроцлавському університеті. Запропоновано результати авторського досвіду щодо створення й використання мап для потреб дистанційного навчання польськомовних студентів-україністів під час пандемії Covid-19. На підставі результатів анкетування останніх стверджено необхідність запровадження та активного застосування візуальних технологій у царині викладання УМІ, що дозволить як оптимізувати процес викладання мови, так і збільшити власний творчий вклад студента у процес її засвоєння.

Ключові слова: візуалізація, ментальна мапа, хмара слів, українська мова як іноземна. 